\title{
HYDROCHEMICAL DATA BASE FOR THE DEATH VALLEY REGION, CALIFORNIA AND NEVADA
}

by Diana L. Perfect, Claudia C. Faunt, William C. Steinkampf and A. Keith Turner

U.S. GEOLOGICAL SURVEY

Open-File Report 94-305

Prepared in cooperation with the NEVADA OPERATIONS OFFICE U.S. DEPARTMENT OF ENERGY

(Interagency Agreement DE-A108-92NV10874)

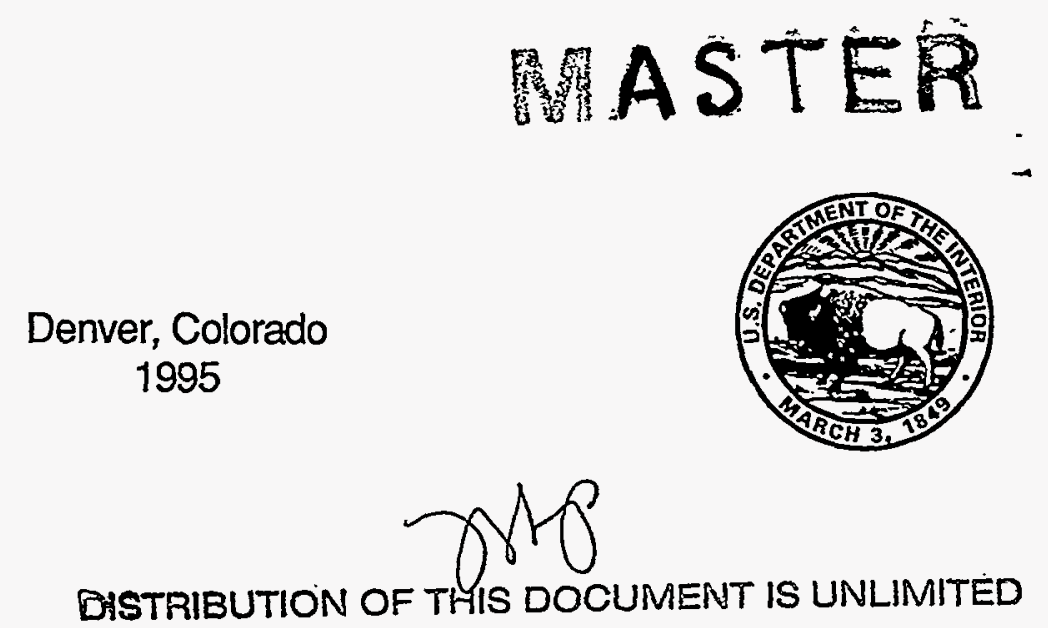




\title{
U.S. DEPARTMENT OF THE INTERIOR BRUCE BABBITT, Secretary
}

\author{
U.S. GEOLOGICAL SURVEY
}

Gordon P. Eaton, Director

\begin{abstract}
DISCLAIMER
This report was prepared as an account of work sponsored by an agency of the United States Government. Neither the United States Government nor any agency thereof, nor any of their employees, makes any warranty, express or implied, or assumes any legal liability or responsibility for the accuracy, completeness, or usefulness of any information, apparatus, product, or process disclosed, or represents that its use would not infringe privately owned rights. Reference herein to any specific commercial product, process, or service by trade name, trademark, manufacturer, or otherwise does not necessarily constitute or imply its endorsement, recommendation, or favoring by the United States Government or any agency thereof. The views and opinions of authors expressed herein do not necessarily state or reflect those of the United States Government or any agency thereof.
\end{abstract}

The use of trade, product, industry, or firm names is for descriptive purposes only and does not imply endorsement by the U.S. Government.

For additional information write to:

Copies of this report can be purchased from:

Chief, Hydrologic Investigations Program

Yucca Mountain Project Branch

U.S. Geological Survey

Box 25046, MS 421

Denver Federal Center

Denver, CO 80225

U.S. Geological Survey

Earth Science Information Center

Open-File Reports Section

Box 25286, MS 517

Denver Federal Center

Denver, CO 80225 


\section{DISCLAIMER}

Portions of this document may be illegible in electronic image products. Images are produced from the best available original document. 


\section{'CONTENTS}

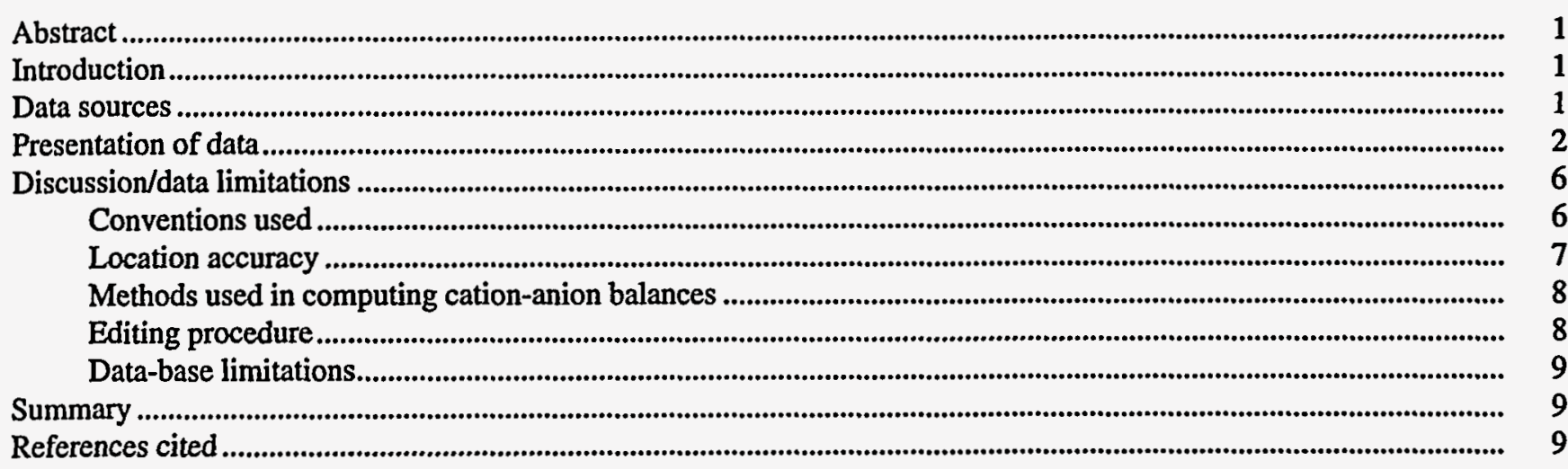

\section{FIGURES}

1. Map showing area of interest

2. Diagram showing lettering conventions used to define locations.

\section{TABLES}

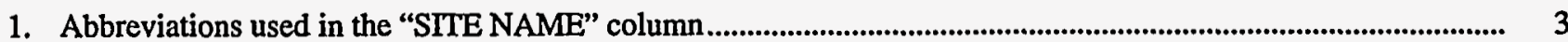

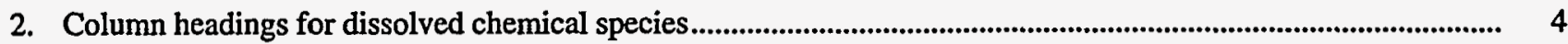

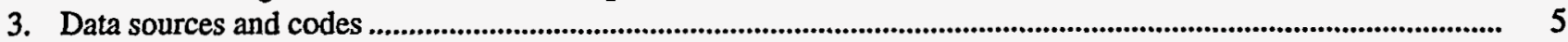

4. Abbreviations used to define the laboratory which performed the chemical analysis........................................... 6

5. Abbreviations used in the "AQUIFER" column.................................................................................................

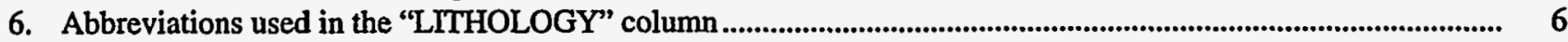

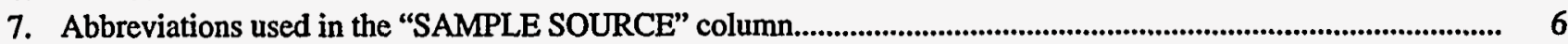

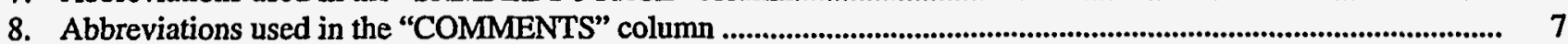

\section{CONVERSION FACTORS}

\begin{tabular}{|c|c|c|}
\hline Multiply metric unit & By & To obtain inch-pound unit \\
\hline $\begin{array}{r}\text { kilometer }(\mathrm{km}) \\
\text { meter }(\mathrm{m})\end{array}$ & $\begin{array}{l}0.6214 \\
3.281\end{array}$ & $\begin{array}{l}\text { mile } \\
\text { foot }\end{array}$ \\
\hline
\end{tabular}

Degree Celsius $\left({ }^{\circ} \mathrm{C}\right)$ may be converted to degree Fahrenheit $\left({ }^{\circ} \mathrm{F}\right)$ by using the following equation:

$$
{ }^{\circ} \mathrm{F}=9 / 5\left({ }^{\circ} \mathrm{C}\right)+32 \text {. }
$$

Sea level: In this report "sea level" refers to the National Geodetic Vertical Datum of 1929 (NGVD of 1929)-a geodetic datum derived from a general adjustment of the first-order level nets of both the United States and Canada, formerly called Sea Level Datum of 1929. 


\title{
Hydrochemical Data Base for the Death Valley Region, California and Nevada
}

\author{
By Diana L. Perfect, Claudia C. Faunt, William C. Steinkampf, andA. Keith Turner
}

\section{Abstract}

Ground-water chemistry data derived from samples collected within an approximately 100,000-square-kilometer area in the Southern Great Basin have been compiled into a digital data base. The data were compiled from published reports, the U.S. Geological Survey (USGS) National Water Information System (NWIS), and previously unpublished USGS files. The data are contained in two compressed files which selfexpand into Lotus (.WK1) files. The first file contains 4,738 records (4.84 megabytes) and represents the basic compilation of all identified analyses. The second file is an edited version of the first and contains 3,733 records (3.84 megabytes). Editing included the removal of duplicate records and the combining of records, when appropriate. The analyses presented are of variable quality and comprehensiveness and include no isotopic data. Of the 3,733 analyses in the edited data base, 58 percent of the major ion concentrations balance to within \pm 10 percent. Most of the remaining records are not sufficiently complete for a balance to be calculated.

\section{INTRODUCTION}

Yucca Mountain, Nevada, is being studied by the U.S. Department of Energy as a potential site for construction of a repository for the permanent storage of high-level radioactive waste. As part of this project, the USGS is engaged in studies to describe the site and the regional geologic and hydrogeologic systems. This compilation of ground-water chemistry data is a part of these studies.

The goal of this effort was to identify and compile existing hydrochemical data within a region bounded by lat $35^{\circ} \mathrm{N}$ to lat $38^{\circ} \mathrm{N}$, and long $115^{\circ} \mathrm{W}$ to long $118^{\circ} \mathrm{W}$. This region includes the Nevada Test Site, Yucca Mountain, and adjacent parts of southern Nevada and eastern California (fig. 1), and encompasses the Death Valley regional ground-water system (Bedinger and others, 1989). The data base was created to enable an assessment of existing data relative to program needs, and to compile the data in a digital format for use in studies utilizing Geographic Information System (GIS) methods.

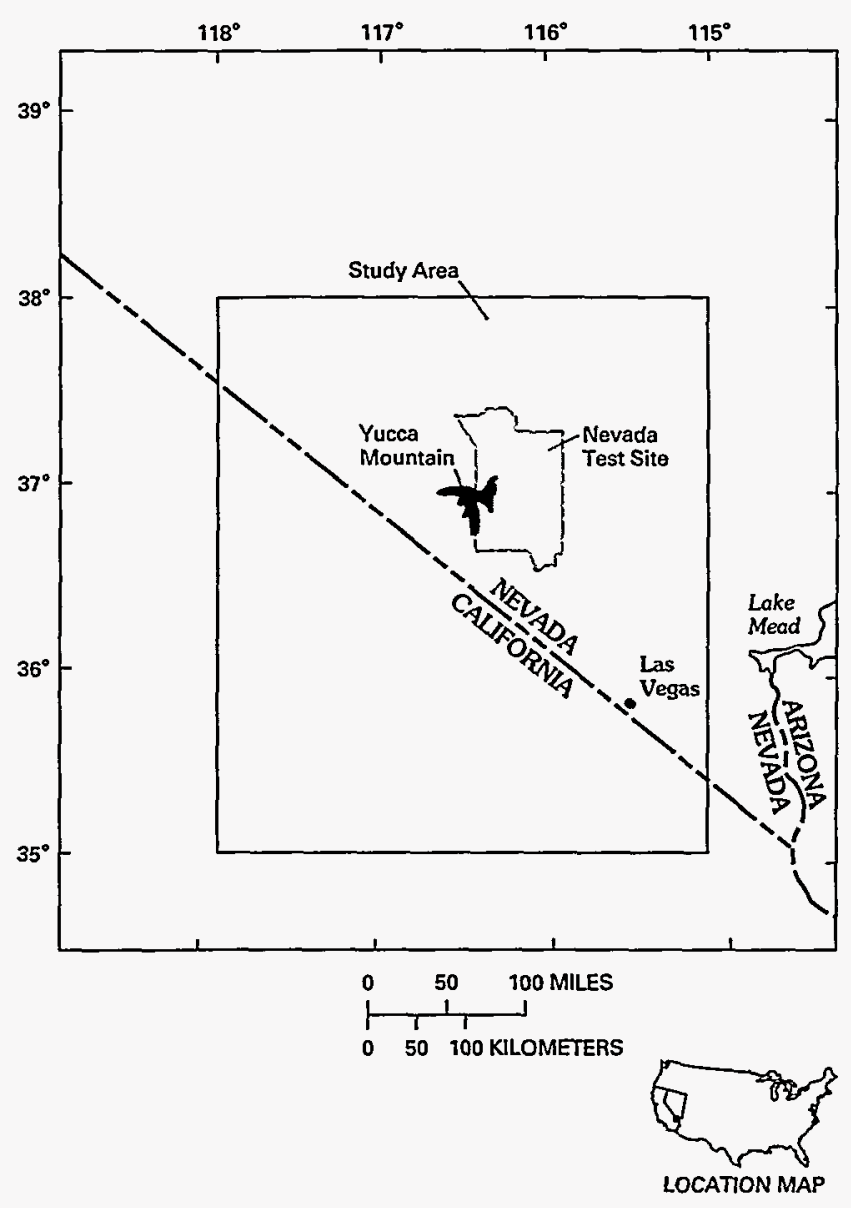

Figure 1. Area of interest.

\section{DATA SOURCES}

Data sources were located through a comprehensive literature search and by canvassing USGS investigators. The chemical analyses forming this data base were identified in four general sources: (1) USGS files of unpublished data, (2) the USGS National Water Information System (NWIS), (3) published reports of investigations by Federal and State agencies, and (4) unpublished data. The data base contains data from 
44 different sources. Dates of the analyses range from 1910 to 1991 . The following is a brief discussion of the data sources that provided most of the compiled information.

Data from over 1,800 original USGS laboratory reports were compiled. These data were collected as part of USGS hydrologic investigations in support of U.S. Department of Energy nuclear weapons testing and date from the early 1950's to the mid 1970's. While many of these were unpublished until now, some have been used in previously published USGS reports.

More than 1,300 analyses were retrieved from the NWIS data base for all available sites within the 3- by 3-degree area of interest (fig. 1) for inclusion in this compilation. Additional, unpublished data were obtained in digital form from Thomas and Welch (in press). Some of these records represent the arithmetic average of several analyses for the same sample site at which concentrations varied only slightly from one analysis to another.

\section{PRESENTATION OF DATA}

Two versions of the data base are available; both are files built using Lotus 1-2-3. The first, UNEDIT, is an unedited file which contains 4,738 records. The second, DATAEDIT, contains 3,733 records and is an edited version of the first. DATAEDIT primarily differs from UNEDIT in that most duplicate records have been removed, some of the records have been made more consistent, and cation-anion balances have been calculated. The information in this report pertains to DATAEDIT.

The files are on two high-density diskettes which accompany this report. They are both in compressed form and are self-expanding as indicated by the .EXE suffix. To expand DATAEDIT.EXE into a file retrievable by Lotus 1-2-3, copy it onto your hard drive and type $<D A T A E D I T$. The size of the expanded file, DATAEDIT.WK1, is 3.84 megabytes. To similarly expand UNEDIT.EXE, type <UNEDIT >. The size of this expanded file, UNEDIT.WK1, is 4.84 megabytes.

The following is a list of the data-base column headings in DATAEDIT. Column headings for UNEDIT are the same, except "BALANCE" is omitted.

1. SITE NAME: This is the name of the site as identified in the source(s) from which information was obtained. Names are presented in more than one format because different sources used different conventions and formats. In many cases, the site location given in the source, in terms of either township and range or Nevada State coordinates, also is shown in this column. At least three different township-and-range conventions are used in the data base. One uses the standard abbreviations for quarter sections: NE (northeast), NW (northwest), SW (southwest), and SE (southeast). In another, each quarter of a quarter section is assigned a unique capital letter, starting with $A$ in the northeast most and ending with $R$ in the southeast most (fig. 2A). In a third convention, the lower-case letters $a, b, c$, and $d$ are used to indicate the northeast, northwest, southwest, and southeast quarters, respectively (fig. 2B). Abbreviations used in this column are listed in table 1.

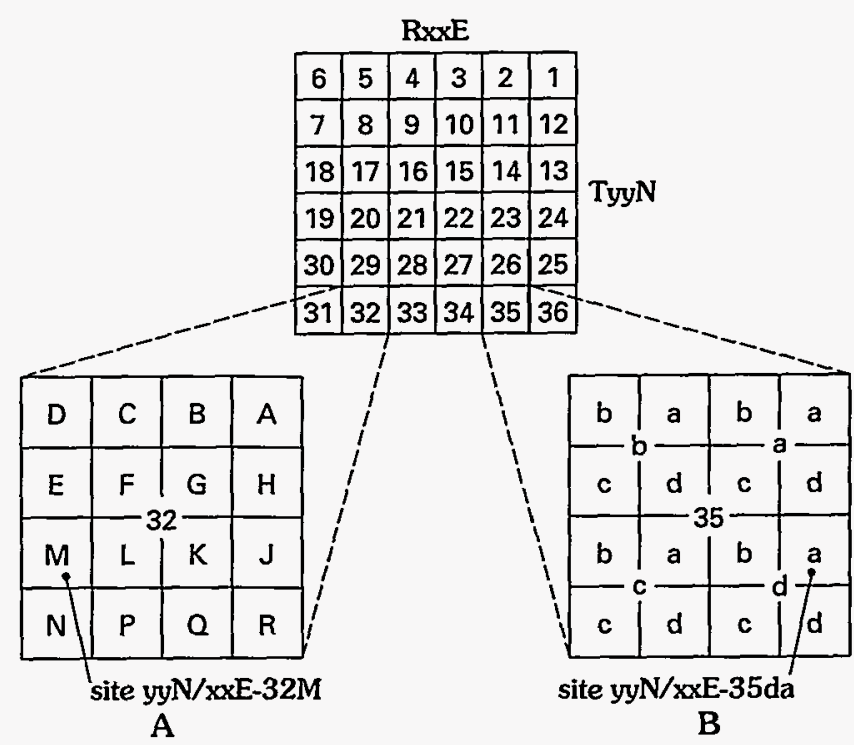

Figure 2. Diagram showing lettering conventions used to define locations.

2. SITE ID: This is an identifier assigned by the USGS to provide a unique means of identifying records within the NWIS. As such, this information is available only for records retrieved from the NWIS. The site identifier is a combination of the latitude and longitude and a two-digit sequence number. The sequence number enables identification of multiple sites with the same latitude and longitude coordinates. The actual latitude and longitude of a site can differ from that in the site identifier, particularly for those established before the 1970's. This is because 
Table 1. Abbreviations used in the "SITE NAME" column

\begin{tabular}{|c|c|}
\hline Abbrevlation & Explanation \\
\hline$\overline{\mathrm{AFB}}$ & Air Force Base \\
\hline ASSC & Association \\
\hline BADWTR, BW & Badwater \\
\hline B & Branch \\
\hline C & California \\
\hline $\mathrm{CO}$ & County, Company \\
\hline $\mathrm{CR}$ & Creek \\
\hline E & East \\
\hline ELEM & Elementary \\
\hline ENG & Engineering \\
\hline FLT & Flat \\
\hline HW & Highway \\
\hline LK & Lake \\
\hline MERC & Mercury (a town) \\
\hline $\mathrm{M}, \mathrm{MI}$ & Mile \\
\hline MTN, MT & Mountain \\
\hline $\mathbf{N}$ & North, or Nevada \\
\hline $\mathrm{NE}$ & Northeast \\
\hline No. & Number \\
\hline NR & Near \\
\hline NTS & Nevada Test Site \\
\hline NW & Northwest \\
\hline OBSERV & Observation \\
\hline $\mathrm{RD}$ & Road \\
\hline RGE, $R$ & Range \\
\hline $\mathbf{R R}$ & Railroad \\
\hline$s$ & South \\
\hline SE & Southeast \\
\hline SEC & Section \\
\hline SPR & Spring \\
\hline ST, STA & Station \\
\hline sw & Southwest \\
\hline $\mathbf{T}$ & Township \\
\hline VY & Valley \\
\hline w & West \\
\hline
\end{tabular}

identifiers often were assigned using a location estimated from topographic maps, the scale and availability of which varied.

3. LATITUDE: North latitude in degrees, minutes, and seconds.

4. LONGITUDE: West longitude in degrees, minutes, and seconds.

5. DATE: Collection date in year/month/day. In the few cases where a range of sample dates were given for one analysis, the most recent one was entered. For USGS files, if no date was given, the "date checked" was used. This is usually the date that the results of the analysis were checked in the laboratory by someone other than the analyst.

6. TIME: Time of sample collection in hours and minutes, given in 24-hour clock time.

7. TEMP: Field temperature of sample in degrees Celsius. If a range was given, the highest temperature was entered.

8. ALK: Alkalinity as calcium carbonate $\left(\mathrm{CaCO}_{3}\right)$ in milligrams/liter ( $\left.\mathrm{mg} / \mathrm{L}\right)$.

9. HARDNESS: Total hardness as $\mathrm{CaCO}_{3}$ in $\mathrm{mg} / \mathrm{L}$.

10. COND: Specific conductance in microSiemens/cm at 25 degrees Celsius.

11. $\mathrm{pH}: \mathrm{pH}$ in standard units. All records from NWIS contain laboratory values. Other records may contain either a field or a laboratory value.

12-51. Dissolved chemical species concentrations, in units of $\mathrm{mg} / \mathrm{L}$ : Column headings listed in table 2.

52. BALANCE: Cation-anion balance. The following abbreviations were used to differentiate among categories established:

B - The analysis balances within \pm 10 percent.

NI - Not enough major ion information is available to calculate a balance.

NB - The analysis balance deviates from ideal by more than 10 percent.

53. DS: A number defining the source of the data entry. The numbers and corresponding references defining each source are provided in table 3.

54. LAB: Abbreviations used to identify the laboratory that performed the analysis. These are listed in table 4.

55. AQUIFER: Information on the sampled interval, which may include perforation data, depth sampled, formation name, or aquifer lithology. Abbreviations are defined in table 5. 
Table 2. Column headings for dissolved chemical species

\begin{tabular}{|c|c|}
\hline $\begin{array}{l}\text { Column } \\
\text { heading }\end{array}$ & $\begin{array}{c}\text { Dissolved } \\
\text { chemical species }\end{array}$ \\
\hline $\mathrm{Ca}$ & Calcium \\
\hline $\mathrm{Mg}$ & Magnesium \\
\hline $\mathrm{Na}$ & Sodium \\
\hline $\mathrm{K}$ & Potassium \\
\hline $\mathrm{Cl}$ & Chloride \\
\hline $\mathrm{SO}_{4}$ & Sulfate \\
\hline $\mathrm{HCO}_{3}$ & Bicarbonate \\
\hline $\mathrm{CO}_{3}$ & Carbonate \\
\hline $\mathrm{PO}_{4}$ & Phosphate \\
\hline $\mathrm{NO}_{3}$ & Nitrate \\
\hline $\mathrm{F}$ & Fluoride \\
\hline $\mathrm{SiO}_{2}$ & Silica \\
\hline As & Arsenic \\
\hline $\mathrm{Ba}$ & Barium \\
\hline $\mathrm{Be}$ & Beryllium \\
\hline B & Boron \\
\hline $\mathrm{Cd}$ & Cadmium \\
\hline $\mathrm{Cr}$ & Chromium \\
\hline Co & Cobalt \\
\hline $\mathrm{Cu}$ & Copper \\
\hline $\mathrm{Fe}$ & Iron $^{1}$ \\
\hline TOTAL Fe & Total iron \\
\hline $\mathrm{Pb}$ & Lead \\
\hline Mn & Manganese \\
\hline Mo & Molybdenum \\
\hline $\mathrm{Ni}$ & Nickel \\
\hline $\mathrm{Ag}$ & Silver \\
\hline $\mathrm{Sr}$ & Strontium \\
\hline V & Vanadium \\
\hline $\mathrm{Zn}$ & Zinc \\
\hline $\mathrm{Li}$ & Lithium \\
\hline $\mathrm{Se}$ & Selenium \\
\hline 1 & Iodide \\
\hline $\mathrm{Br}$ & Bromide \\
\hline TOTAL N & Total nitrogen \\
\hline $\mathrm{Hg}$ & Mercury \\
\hline DO & Dissolved oxygen \\
\hline DOC & Dissolved organic carbon \\
\hline TDS & $\begin{array}{l}\text { Total dissolved solids } \\
\text { (residue on evaporation at } \\
180 \text { degrees Celsius) }\end{array}$ \\
\hline
\end{tabular}

\footnotetext{
'In some cases, the value reported for iron was not clearly defined. Each iron value was entered into the "Fe" column, unless it was indicated to be "total iron," in which case, it was entered into the "TOTAL Fe" column.
}

56. LITHOLOGY: Abbreviations for aquifer lithologies or textures, listed in table 6.

57. SAMPLE SOURCE: Abbreviations identifying the general source type. In cases where no source was indicated, and for which it was deemed likely, it was assumed that the source was a well; otherwise, the column was left blank. Table 7 lists the abbreviations used.

58. COMMENTS: A collection of general information regarding the sample and/or site, such as sample appearance, well completion information, and additional hydrochemical data. Casing depth, if available and different from total well depth, is listed here. Table 8 lists the abbreviations used.

The following columns were not part of the data base when data were first being entered and therefore are not complete. Some of the data sources may have had information on altitude, well depth, and water level that was not entered as a result of the later inclusion of these columns.

59. ALTITUDE: Altitude of land surface at well head, with respect to sea level, in feet.

60. WELL DEPTH: Depth to base of well below land surface, in feet.

61. WATER DEPTH: Depth to water below land surface, in feet.

62. WL ALT: Water-level altitude, in feet. The datums used to measure water levels and well depths were variable. In the cases where the datum was not clearly indicated, it was assumed to be land surface. Because the datum most commonly noted was either the altitude of the casing top or land surface, any error resulting from this assumption should be at most a few feet. 
Table 3. Data sources and codes

\begin{tabular}{|c|c|}
\hline $\begin{array}{c}\text { Data } \\
\text { source } \\
\text { code }\end{array}$ & Data Sources \\
\hline 1 & Benson and McKinley, 1985 \\
\hline 2 & Benson and others, 1983 \\
\hline 3 & Blankennagel and Weir, 1973 \\
\hline 4 & Calzia, 1979a \\
\hline 5 & Calzia, $1979 b$ \\
\hline 6 & Claassen, 1973 \\
\hline 7 & Claassen, 1983 \\
\hline 8 & Claassen, H.C., U.S. Geological Survey, unpublished data \\
\hline 9 & Cooperative Extension U.S. Department of Agriculture \\
\hline 10 & Craig and Robison, 1984 \\
\hline 11 & Crowley, 1979a \\
\hline 12 & Crowley, 1979b \\
\hline 13 & Czarnecki, J., U.S. Geological Survey, unpublished data \\
\hline 14 & Dockter and Server, 1979 \\
\hline 15 & Dockter, 1979 \\
\hline 16 & Dudley and Larson, 1976 \\
\hline 17 & Environmental Protection Agency (EPA), unpublished data \\
\hline 18 & Glancy, 1968 \\
\hline 19 & Hardman and Miller, 1934 \\
\hline 20 & Hunt and others, 1966 \\
\hline 21 & Lahoud and others, 1984 \\
\hline 22 & Malmberg and Eakin, 1962 \\
\hline 23 & Malmberg, 1967 \\
\hline 24 & Miller, 1977 \\
\hline 25 & Moore, 1961 \\
\hline 26 & U.S. Geological Survey, National Water Data Storage and Retrieval System (WATSTORE) \\
\hline 27 & Nichols and Davis, 1979 \\
\hline 28 & Robinson and Beetem, 1975 \\
\hline 29 & Rush, 1968 \\
\hline 30 & Schaefer and others, 1992 \\
\hline 31 & Schoff and Moore, 1964 \\
\hline 32 & Thomas and others, 1991 \\
\hline 33 & Thomas, J. (written communication, 1989) \\
\hline 34 & U.S. Energy Research and Development Administration \\
\hline 35 & U.S. Geological Survey, National Water Information System (NWIS-I) \\
\hline 36 & U.S. Geological Survey, unpublished data \\
\hline 37 & Waddell, 1984 \\
\hline 38 & Walker and Eakin, 1963 \\
\hline 39 & White, 1979 \\
\hline 40 & Winograd and Thordarson, 1975 \\
\hline 41 & Winograd, U.S. Geological Survey, unpublished data \\
\hline 42 & Whitfield and others, 1985 \\
\hline 43 & Whitfield, U.S. Geological Survey, unpublished data \\
\hline 44 & Young, 1972 \\
\hline
\end{tabular}


Table 4. Abbreviations used to define the laboratory which performed the chemical analysis

\begin{tabular}{ll}
\hline Abbreviatlon & \multicolumn{1}{c}{ Laboratory } \\
\hline CA DPH & Califormia Department of Public Health \\
CA DWR & California Department of Water Resources \\
DHEW & U.S. Department of Health, Education, and \\
& Welfare \\
DRI & Desert Research Institute \\
EPA & Environmental Protection Agency \\
LVWD & Las Vegas Water District \\
NAT PARK & National Park Service \\
NDH & Nevada Department of Health \\
NSHL & Nevada State Health Laboratory \\
NWQL & National Water Quality Laboratory \\
USBR & U.S. Bureau of Reclamation \\
USDA & U.S. Department of Agriculture \\
USGS & U.S. Geological Survey \\
X & No laboratory information available \\
\hline
\end{tabular}

Table 5. Abbreviations used in the "AQUIFER" column

\begin{tabular}{ll}
\hline Abbreviation & \multicolumn{1}{c}{ Explanation } \\
\hline DOLO & Dolomite, dolomitic \\
FM & Formation \\
GW & Ground water \\
LMY & Limey \\
LS & Limestone \\
LT & Light \\
PERFS & Perforations \\
PZC, PC & Paleozoic carbonate rocks \\
QT & Quaternary \\
QTAL, QAL & Quarternary alluvium \\
SLM & Silurian Lone Mountain Dolomite \\
SPR & Spring \\
SRM & Silurian Roberts Mountain Formation \\
SS & Sandstone \\
Tcb & Tertiary Bullfrog Member of Crater Flat \\
& Tuff \\
Tct & Tertiary Crater Flat Tuff \\
TD & Total depth \\
Th & Tertiary tuffaceous beds of Calico Hills \\
Tos & Tertiary Oak Spring Formation \\
TV & Tertiary volcanic rocks \\
W & With \\
X & No aquifer information available \\
\hline
\end{tabular}

Table 6. Abbreviations used in the "LITHOLOGY" column

\begin{tabular}{ll}
\multicolumn{1}{c}{ Abbreviation } & \multicolumn{1}{c}{ Explanation } \\
\hline CARB & Carbonate(s) \\
DOLO & Dolomite \\
FRAC & Fractured \\
LS & Limestone \\
PC, PZ, PZCA, PZC & Paleozoic carbonate rocks \\
QAL, QTAL & Quarternary alluvium \\
QTZ & Quartzite \\
SH & Shale \\
SS & Sandstone \\
TAL & Tertiary alluvium \\
TRAV & Travertine \\
TV & Tertiary volcanic rocks \\
WELD & Welded \\
X & No lithologic information available \\
ZEO & Zeolitic \\
\hline
\end{tabular}

Table 7. Abbreviations used in the "SAMPLE SOURCE" column

\begin{tabular}{ll}
\hline Abbreviation & \multicolumn{1}{c}{ Explanation } \\
\hline CT & Cable tool \\
DR & Drilled \\
EXPLOR & Exploration \\
FRAC & Fracture \\
GW & Ground water \\
INFHTRA & Infiltration \\
STA & Station \\
TUN & Tunnel \\
X & No sample source indicated \\
\hline
\end{tabular}

\section{DISCUSSION/DATA LIMITATIONS}

\section{Conventions Used} lows:

Conventions used in entering the data are as fol-

1. In general, “-99998” indicates that either no data were available or the reported value was indicated to be a "trace amount." In the case of the "incomplete" columns (ALTITUDE, WELL 
DEPTH, WL ALT, and WATER DEPTH), it also can mean that no data were entered.

2. A negative chemical concentration value indicates that the concentration is "less than" the absolute value of the number listed.

Table 8. Abbreviations used in the "COMMENTS" column

\begin{tabular}{|c|c|}
\hline Abbreviation & Explanation \\
\hline ALLUV & Alluvium \\
\hline $\mathrm{BI}$ & Bismuth \\
\hline BLK & Black \\
\hline BOUND & Boundary \\
\hline BRN & Brown \\
\hline BX & Borax \\
\hline CARB & Carbonate \\
\hline $\mathrm{CO}$ & County \\
\hline COLLUV & Colluvium \\
\hline COOR & Coordinates \\
\hline CSE TD & Casing run to total depth \\
\hline COMMUN & Communication \\
\hline DK & Dark \\
\hline DSTRBUTARY & Distributary \\
\hline DIV & Division \\
\hline DOLO & Dolomite \\
\hline $\mathbf{E}$ & East \\
\hline FM & Formation \\
\hline FR & From \\
\hline FRAC & Fractured \\
\hline GA & Gallium \\
\hline GE & Germanium \\
\hline GRN & Green \\
\hline LAT/LONG & Latitude and longitude \\
\hline LI & Lithium \\
\hline $\mathrm{LT}$ & Light \\
\hline LS & Limestone \\
\hline LOC & Location \\
\hline $\mathbf{M}$ & Meters \\
\hline MEAS & Measured \\
\hline MI & Miles \\
\hline MIN & Minutes \\
\hline ML & Milliliters \\
\hline MTN & Mountain \\
\hline $\mathbf{N}$ & North \\
\hline NEV & Nevada \\
\hline NR & Near \\
\hline NTS & Nevada Test Site \\
\hline
\end{tabular}

Table 8. Abbreviations used in the "COMMENTS" column --Continued

\begin{tabular}{ll}
\hline Abbrevlation & \multicolumn{1}{c}{ Explanation } \\
\hline OH & Hydroxide \\
PC, PZC & Paleozoic carbonate rocks \\
PERF & Perforations, perforated \\
PHREATO & Phreatophytes \\
PICKLEWD & Pickleweed \\
PPM & Parts per million \\
PROB & Probably \\
QAL, QTAL & Quarternary alluvium \\
QUAD & Quadrangle \\
QUANT, Q & Quantitative \\
PROD & Production \\
RB & Rubidium \\
S & South \\
SALTGR & Saltgrass \\
SE & Selenium \\
SE & Sediment \\
SLI & Slightly \\
SPR & Spring \\
SN & Tin \\
ST & State \\
STA & Station \\
SR & Strontium \\
T & Temperature \\
TABL, TBL & Table \\
TD & Total depth \\
VEG & Vegetation \\
W & With \\
WL & Water level \\
WH & Well head \\
WTR & Water \\
X & No comments \\
\hline
\end{tabular}

\section{Location Accuracy}

When not given in the respective sources, the latitude and longitude of each site were determined and are included in the data base. For many sites, the sources provided locations only in terms of township and range or Nevada State plane coordinates. These were converted to latitude and longitude before entry into the data base. The Nevada State plane coordinates were converted using projection definitions provided by the geographic information system ARC/INFO. Township and range locations were converted to latitudes and longitudes by direct measurements from topographic maps at scale $1: 100,000$, utilizing either a 
variable scale or a digitizer. If the data source had a discrepancy between the township and range location and the latitude and longitude, the latitude and longitude were assumed to be correct. Locations of sites for which only the name of the well or spring were given were determined as accurately as possible using any available sources, such as reports or maps. In some cases, the information was not clear and judgment had to be used to assign a location. In general, sample locations are accurate to within 1 kilometer. Most are much more precisely located than that; a few, however, may be less accurate.

\section{Methods Used in Computing Cation-Anion Balances}

Conventions and assumptions used in balancing the analyses are as follows:

1. All "less than" values were assumed to be equal to zero.

2. In most cases, the major cations (calcium, magnesium, sodium, and potassium) and the major anions (bicarbonate, carbonate, sulfate, and chloride) were used to balance the analyses.

3. When bicarbonate and carbonate data were not given, alkalinity, if available, was used to estimate a bicarbonate concentration. In the cases where cation data were inadequate to calculate a balance, an attempt was made to use hardness to estimate the sum of calcium and magnesium concentrations. Only a few analyses were balanced using these estimating procedures.

4. A few analyses were balanced by including fluoride data. For others, some ion pairs such as sodium and potassium or bicarbonate and carbonate were summed together in the data source and therefore could not be separately entered into the data base. The combined data, however, were used to balance the analyses by assuming that the reported concentrations represented those of the major ion of the pair.

5. Analyses that did not balance initially were checked for errors and inconsistencies in the data. Several records were balanced after such problems were corrected.

\section{Editing Procedure}

The original data compilation, UNEDIT, contains 4,738 analyses, some of which are duplicates or near duplicates. Near duplicates are records which are not completely identical because they were obtained from different sources. In the edited file, DATAEDIT, actual duplicate records were removed. In addition, many discrepancies in near duplicates were resolved and the records were combined. The individual sources of combined records are noted in the datasource column. Identifiable errors in the data were corrected during editing.

The minor discrepancies in near-duplicate records were due to different reporting formats in the original sources and were of three types. The first type occurred when one or more of the records contained data that were not in the others. In these cases, the data were combined into one record. The second type was a discrepancy in one or more parameter values. In these cases, an attempt was made to determine which record was correct. If a copy of the original laboratory report could be located, it was used to select the correct value and the other value was removed from the data base. If the discrepancy could not be resolved, both records were left in the data base. The third type of discrepancy was due to different conventions used in reporting the data. Discrepancies of this type were most common in the minor element data. For example, three near-duplicate records may show manganese values of $<0.01,0.01$, and 0.0. Again, if a copy of the original laboratory report was available, it was used to select the correct value and the other value was removed from the data base. If the discrepancy could not be resolved, two records were left in the data base, one containing <.01 and one containing 0.0. Another example would be the case of five records, three showing a value of 0.2 for a certain element and two showing 0.5 . In this case, if the discrepancy could not be resolved, two records would be left in the data base, one showing 0.2 and one showing 0.5 . In general, there were more discrepancies for iron than for any other minor element. This was probably due to the different ways in which iron concentrations were expressed and because the convention used often was not clearly stated. Some other conventions were used when combining near-duplicate records showing discrepancies in either alkalinity or $\mathrm{pH}$. For discrepancies in alkalinity, the highest value was chosen; for $\mathrm{pH}$, the lowest value was chosen.

The final step in editing was to resolve location discrepancies among multiple records for a single well or spring so that all were assigned the same location in terms of latitude and longitude. In general, the NWIS 
locations were considered to be most accurate and were given precedence. Next were the locations as shown in USGS Open-File Report 90-355 (McKinley and others, 1991). Locations given in other USGS reports were used for sampling locations not contained in either of the first two sources.

\section{Data-Base Limitations}

Based on the completeness of individual analyses and on their calculated cation-anion balances, the analytical data contained in the data base are of variable utility. Of the 3,733 analyses in the edited data base, 58 percent $(2,178)$ balanced to within \pm 10 percent. Of the remaining records, 1,373 did not contain enough major ion data to calculate a balance.

The data base has some deficiencies. No distinction was made between field and laboratory $\mathrm{pH}$. Field and laboratory inorganic carbon values (bicarbonate, carbonate, alkalinity) also were not differentiated. In addition, stable and radioisotopic data were omitted. These data, which are available for some sites, include deuterium $\left(\delta^{2} \mathrm{H}\right)$, tritium $\left({ }^{3} \mathrm{H}\right)$, oxygen $\left(\delta^{18} \mathrm{O}\right)$, carbon $\left(\delta^{13} \mathrm{C}\right.$ and $\left.{ }^{14} \mathrm{C}\right)$, strontium $\left(\delta^{87} \mathrm{Sr}\right.$ and $\left.{ }^{90} \mathrm{Sr}\right)$, and a few other radionuclides. The majority of the isotopic data available comprise $\delta^{2} \mathrm{H},{ }^{3} \mathrm{H}$, and $\delta^{18} \mathrm{O}$ values.

More than one abbreviation convention was sometimes used in the data-base columns. This is a result of using multiple sources and the way in which the data base was developed.

\section{SUMMARY}

Ground-water chemistry data have been compiled for the Yucca Mountain, Nevada, regional area. Primary sources for the data were USGS files, USGS National Water Information Systems (NWIS), and published reports. The data are contained in two compressed files which self-expand into Lotus (.WK1) files, an unedited version, UNEDIT, containing 4,738 records and an edited version, DATAEDIT, containing 3,733 records. Editing included the removal of duplicate records and the combining of records, when appropriate. In addition, some errors were removed and some records made more consistent.

The analyses presented are of variable quality and comprehensiveness and include no isotopic data. Of the 3,733 analyses in the edited data base, 58 percent $(2,178)$ can be balanced to within \pm 10 percent, 37 percent are not sufficiently complete for a balance to be calculated.

\section{REFERENCES CITED}

Bedinger, M.S., Sargent, K.A., and Langer, W.H., 1989, Studies of geology and hydrology in the basin and range province, southwestern United States, for isolation of high-level radioactive waste-characterization of the Death Valley region, Nevada and California: U.S. Geological Survey Professional Paper 1370-F, 49 p. (NNA.920131.0251)

Benson, L.V., and McKinley, P.W., 1985, Chemical composition of ground water in the Yucca Mountain area, Nevada-An update: U.S. Geological Survey OpenFile Report 85-484, 10 p. (HQS.880517.1890)

Benson, L.V., Robison, J.H., Blankennagel, R.K., and Ogard, A.E., 1983, Chemical composition of ground water and the location of permeable zones in the Yucca Mountain area, Nevada: U.S. Geological Survey OpenFile Report 83-854, 19 p. (NNA.890511.0102)

Blankenagel, R.K., and Weir, J.E., Jr., 1973, Geohydrology of the eastern part of Pahute Mesa, Nevada Test Site: U.S. Geological Survey Professional Paper 712-B, p. B1-B35. (HQS.880517.1733)

Calzia, J.P., 1979a, Geophysical, lithologic, and water quality data from Ivanpah Valley, San Bernardino County, California: U.S. Geological Survey Open-File Report. (NNA.940510.0002)

Calzia, J.P., 1979b, Geophysical, lithologic, and water quality data from Soda Dry Lake, San Bernardino County, California: U.S. Geological Survey Open-File Report. (NNA.940510.0003)

Claassen, H.C., 1973, Water quality and physical characteristics of Nevada Test Site water-supply wells: U.S. Geological Survey USGS-474-158, 145 p. (HQS.880517.1740)

Claassen, H.C., 1983, Sources and mechanisms of recharge for ground water in the west-central Amargosa Desert, Nevada-A geochemical interpretation: U.S. Geological Survey Open-File Report 83-542, 61 p. (NNA.870406.0176)

Craig, R.W., and Robison, J.H., 1984, Geohydrology of rocks penetrated by test well UE-25p \#1, Yucca Mountain area, Nye County, Nevada: U.S. Geological Survey Water-Resources Investigations Report 84-4248, 57 p. (HQS.880517.1133)

Crowley, J.A., 1979a, Geophysical, lithologic, and water quality data from Eureka Valley, Inyo County, California: U.S. Geological Survey Open-File Report. (NNA.940510.0004)

Crowley, J.A., 1979b, Geophysical, lithologic, and water quality data from Franklin Dry Lake, Inyo County, California: U.S. Geological Survey Open-File Report. (NNA.940510.0005)

Dockter, R.D., 1979, Geophysical, lithologic, and water quality data from test wells on Cuddeback Dry Lake, San Bernardino County, California: U.S. Geological Survey Open-File Report. (NNA.940510.0007) 
Dockter, R.D., and Server, G.T., 1979, Geophysical, lithologic, and water quality data from test well on Coyote Dry Lake, San Bernardino County, California: U.S. Geological Survey Open-File Report. (NNA.940510.0006)

Dudley, W.W., and Larson, J.D., 1976, Effect of irrigation pumping on Desert Pupfish habitats in Ash Meadows, Nye County, Nevada: U.S. Geological Survey Professional Paper 927, 26 p. (NNA.870518.0076)

Glancy, P.A., 1968, Water-resources appraisal of MesquiteIvanpah Valley area, Nevada and California: Nevada Division of Water Resources, Water ResourcesReconnaissance Series Report 46, 57 p. (NNA.940520.0075)

Hardman, George, and Miller, M.R., 1934, The quality of the waters of southeastern Nevada, drainage basins and water resources: The University of Nevada Agricultural Experiment Station, Bulletin No. 136, University of Nevada, Reno, Nevada, 62 p. (NNA.940520.0076)

Hunt, C.B., Robinson, T.W., Bowles, W.A., and Washburn, A.L., 1966, Hydrologic basin, Death Valley, California: U.S. Geological Survey Professional Paper 494-B, 138 p. (HQS.880517.1781)

Lahoud, R.G., Lobmeyer, D.H., and Whitfield, M.S., Jr., 1984, Geohydrology of volcanic tuff penetrated by test well UE-25b \#1, Yucca Mountain, Nye County, Nevada: U.S. Geological Survey Water-Resources Investigations Report 84-4253, $44 \mathrm{p}$. (NNA.890511.0117)

Malmberg, G.T., and Eakin, T.E., 1962, Ground-water appraisal of Sarcobatus Flat and Oasis Valley, Nye and Esmeralda Counties, Nevada: Nevada Department of Conservation and Natural Resources, Ground-Water Resources-Reconnaissance Series Report 10, 39 p. (NNA.870406.0429)

Malmberg, G.T., 1967, Hydrology of the valley-fill and carbonate-rock reservoirs, Pahrump Valley, NevadaCalifornia: U.S. Geological Survey. Water-Supply Paper 1832, 47 p. (NNA.870406.0430)

McKinley, P.W., Long, M.P., and Benson, L.V., 1991, Chemical analyses of water from selected wells and springs in the Yucca Mountain area, Nevada and southeastern California: U.S. Geological Survey Open-File Report 90-355, 47 p. (NNA.901031.0004)

Miller, G.A., 1977, Appraisal of the water resources of Death Valley, California-Nevada: U.S. Geological Survey Open-File Report 77-728, 70 p. (HQS.880517.1934)

Moore, J.E., 1961, Records of wells, test holes, and springs in the Nevada Test Site and surrounding area: U.S. Geological Trace-Elements Investigations Report 781, 22 p. (NNA.901026.0052)

Nichols, W.D., and Davis, L.E., 1979, Data on groundwater resources of the Spring Mountain area, Toiyabe National Forest, Nevada: U.S. Geological Survey Open-File Report 79-1638, 16 p. (NNA.901026.0054)
Robinson, B.P., and Beetem, W.A., 1975, Quality of water in aquifers of the Amargosa Desert and vicinity, Nevada: U.S. Geological Survey Report USGS-474-215, 64 p. (NNA.901026.0056)

Rush, F.E., 1968, Water-resources appraisal of Clayton Valley-Stonewall Flat area, Nevada and California: Nevada Department of Conservation and Natural Resources, Water Resources-Reconnaissance Series Report 45, 53 p. (NNA.940520.0077)

Schaefer, D.H., Morris, T.M., and Dettinger, M.D., 1992, Hydrogeologic and geophysical data for selected wells and springs in the sheep range area, Clark and Lincoln Counties, Nevada: U.S. Geological Survey Open-File Report 89-425, 26 p. (NNA.940520.0078)

Schoff, S.L., and Moore, J.E., 1964, Chemistry and movement of ground water, Nevada Test Site: U.S. Geological Survey Trace-Elements Investigations Report 838, 75 p. (NNA.870518.0062)

Thomas, J.M., Lyles, B.F., and Carpenter, L.A., 1991, Chemical and isotopic data for water from wells, springs, and streams in carbonate-rock terrane of southern and eastern Nevada and southeastern California, 1985-88: U.S. Geological Survey Open-File Report 89-422, 24 p. (NNA.940510.0008-0009)

Thomas, J.M., and Welch, A.H., in press, Geochemistry and isotope hydrology of representative aquifers in the Great Basin Region of Nevada, Utah, and adjacent states: U.S. Geological Survey Professional Paper 1409-C. (MOL.19940714.0109)

Waddell, R.K., 1984, Hydrologic and drill-hole data for test wells UE-29a \#1 and UE-29a \#2, Fortymile Canyon, Nevada Test Site: U.S. Geological Survey Open-File Report 84-142, 25 p. (NNA.870406.0055)

Walker, G.E., and Eakin, T.E., 1963, Geology and ground water of Amargosa Desert, Nevada-California: Nevada Department of Conservation and Natural Resources, Ground-Water Resources-Reconnaissance Series Report 14, 45 p. (HQS.880517.1862)

White, A.F., 1979, Geochemistry of ground water associated with tuffaceous rocks, Oasis Valley, Nevada: U.S. Geological Survey Professional Paper 712-E, p. E1-E25. (NNA.870517.0034)

Whitfield, M.S., Eshom, E.P., Thordarson, William, and Schaefer, D.H., 1985, Geohydrology of test well USW H-4, Yucca Mountain, Nye County, Nevada: U.S. Geological Survey Water-Resources Investigations Report 85-4030, 33 p. (NNA.880517.1870)

Winograd, I.J., and Thordarson, William, 1975, Hydrologic and hydrochemical framework, south-central Great Basin, Nevada-California, with special reference to the Nevada Test Site: U.S. Geological Survey Professional Paper 712-C, p. C1-C126. (NNA.870406.0201)

Young, R.A., 1972, Water supply for Nuclear Rocket Development Station at the U.S. Atomic Energy Commission's Nevada Test Site: U.S. Geological Survey Water-Supply Paper 1938, 19 p. (NNA.870519.0070) 